GLOBAL JOURNAL OF GEOLOGICAL SCIENCES VOL. 16, 2018: 63-78

COPYRIGHTO BACHUDO SCIENCE CO. LTD PRINTED IN NIGERIA ISSN 1596-6798

www.globaljournalseries.com, Email: info@globaljournalseries.com

\title{
GEOCHEMISTRY OF EKENKPON AND NKPORO SHALES, CALABAR FLANK, SE NIGERIA: IMPLICATIONS FOR PROVENANCE, TRANSPORTATION HISTORY AND DEPOSITIONAL ENVIRONMENT
}

\author{
MATTHEW E. NTON, OTO S. AKPAN AND OLAJIDE J. ADAMOLEKUN
}

(Received 6 April 2017; Revision Accepted 26 June 2017)

\begin{abstract}
The Cretaceous Nkporo and Ekenkpon Shales within the Calabar Flank were investigated using Inductively Coupled Plasma-Mass Spectroscopy (ICP-MS) and Atomic Emission Spectroscopy (ICP-AES) to deduce the provenance, transportation history and depositional environment. The results show the dominance of $\mathrm{SiO}_{2}(45.27-46.45 \%$; 44.50 - 54.83\%), $\mathrm{Al}_{2} \mathrm{O}_{3}(22.27-23.57 \% ; 19.20-20.20 \%)$ and $\mathrm{Fe}_{2} \mathrm{O}_{3}(8.30-9.04 \% ; 5.64-7.30 \%)$ constituting the bulk major oxides of Nkporo and Ekenkpon Shales respectively. The Index of Chemical Variation (ICV) ranges from 0.42 0.56 and $0.57-0.68$ for Nkporo and Ekenkpon Shales respectively, suggesting moderate and high degree of weathering. The enrichment of Sr (124-350ppm; Nkporo Shale and 176-856ppm; Ekenkpon Shale) compared to Post Australian Archean Shale (PAAS; 14.6ppm) could be attributed to feldspars in the source area, and is easily incorporated in the clay minerals of the shales. Also the values of Th and $U$ which are $15.00-17.20 \mathrm{ppm} ;$ 14.623.2ppm and 3.5-4.2ppm; 1.9-6.2ppm respectively in Nkporo and Ekenkpon sediments show enrichment compared to PAAS of $14.6 \mathrm{ppm}$ and $3.1 \mathrm{ppm}$ for respective values of Th and $U$. The Eu anomaly of 0.04 to 0.07 suggests felsic source rocks for both formations while plots of $\mathrm{TiO}_{2}$ vs. $\mathrm{Al}_{2} \mathrm{O}_{3}$ indicate an intermediate to dominantly felsic granodiorite source for both shales, with little input from felsic volcanic provenance plus traces of quartzose sedimentary rocks. The mobility of $\mathrm{Na}, \mathrm{Ca}$, and $\mathrm{K}$ due to progressive weathering of the shales is evident in the bivariate plots of $\mathrm{Na}_{2} \mathrm{O}$ wt $\%$ vs. PIA, CaOwt\% vs. PIA and $\mathrm{K}_{2} \mathrm{O}$ vs. PIA. Values of Th/U ratios range from $3.37-4.91$ (Nkporo) and $3.10-7.68$ (Ekenkpon), indicating moderate to high weathering and reworking of sediments. It is envisaged that the area is associated with passive to active continental margin tectonics, where sediments were mainly sourced from felsic rocks of the adjoining terrain and deposited in oxic, continental to transitional marine environment based on $\mathrm{Al}_{2} \mathrm{O}_{3}-$ $\mathrm{K}_{2} \mathrm{O}+\mathrm{CaO}+\mathrm{MgO}-\mathrm{Fe}_{2} \mathrm{O}_{3}+\mathrm{MgO} ; \mathrm{AKF}$ plot.
\end{abstract}

KEYWORDS: Cretaceous, Calabar Flank, provenance, transportation history, depositional environment.

\section{INTRODUCTION}

The Calabar Flank is that part of the southern Nigerian sedimentary basin, bordered by the Oban Massif to the north, the Niger Delta to the south, the Cameroon volcanic ridge to the east, Ikpe platform to the west, and Afikpo syncline to the northwestern (Fig. 1; Murat, 1972). The Cretaceous - Tertiary successions in the basin represents a post -rift basin-fill, containing about $4 \mathrm{~km}$ of fluvial-continental, marine and paralic sediments (Odumodu, 2012).

Several studies have been carried out on various lithostratigraphic units of the Calabar Flank to ascertain its geology, and economic potentials with much success recorded in the limestone, sandstone and marl bearing formations as they are raw materials for cement, sources of ground water and construction materials (Ekwueme, 1985; Reijers and Petters, 1987; Esu and Okereke, 1990; Ekwere, 1993; Ekwere et al., 1994 and Edet and Okereke, 2002) among others. Earlier geological studies were based on tectonics, field associations, biostratigraphy and sedimentological descriptions of these Cretaceous sedimentary rocks as exposed at different outcrops locations. Such works include: Reyment (1965); Dessauvagie, (1974); Adeleye and Fayose (1978); Petters, 1980; 1982; Petters and Ekweozor (1982), Akpan, 1985; Nyong and Ramanathan, ( 1985) ; Petters et al. (1995) .

Organic geochemical appraisal of the associated shales and limestones within the Calabar Flank have been reported by Essien et al. (2005); Ekpo et al., (2012), Ekot et al.,(2014) ; Boboye and Okon (2014). Boboye and Okon (2014), worked on sedimentological and geochemical characterization of the sediments of Calabar Flank by using petrography, inorganic and organic geochemical studies to deduce the provenace, depositional environment, hydrocarbon potential as well as tectonic setting of the area .

However, most of the previous work within the Calabar Flank centred on aspects of lithostratigraphy, organic geochemistry, biostratigraphy and sedimentology. Detailed inorganic geochemical assessments of the sediments have not been fully examined distinctly apart from a few (Ekwueme, 1985;

Matthew E. Nton, Department of Geology, University of Ibadan, Ibadan, Nigeria.

Oto S. Akpan, Department of Geology, University of Ibadan, Ibadan, Nigeria.

Olajide J. Adamolekun, Department of Geology, University of Ibadan, Ibadan, Nigeria. 
Ekwere, 1993; Elueze et al. 1999; Okon et al., 2017). It is known that among sedimentary rocks, shales are considered to retain most of their mineral constituents of the source and their bulk chemistry preserved the nearoriginal geochemical constituents of the provenance and reveal the palaeo-weathering conditions (Pettijohn, 1975). In addition, they represent the average crustal composition of the provenance much better than any other rock type. The elemental composition of shales can therefore be used to deduce the source, tectonics, transportation history and depositional environment of such sediments (Nesbitt and Young, 1984; Bhatia, 1983; Roser and Korsch, 1988; Condie, 1993; McLennan et al., 1993; Cullers, 2000).

This study examines the elemental composition of the Ekenkpon and Nkporo shales within the Calabar Flank and attempts to constrain their provenance, transportation history and environment of deposition.

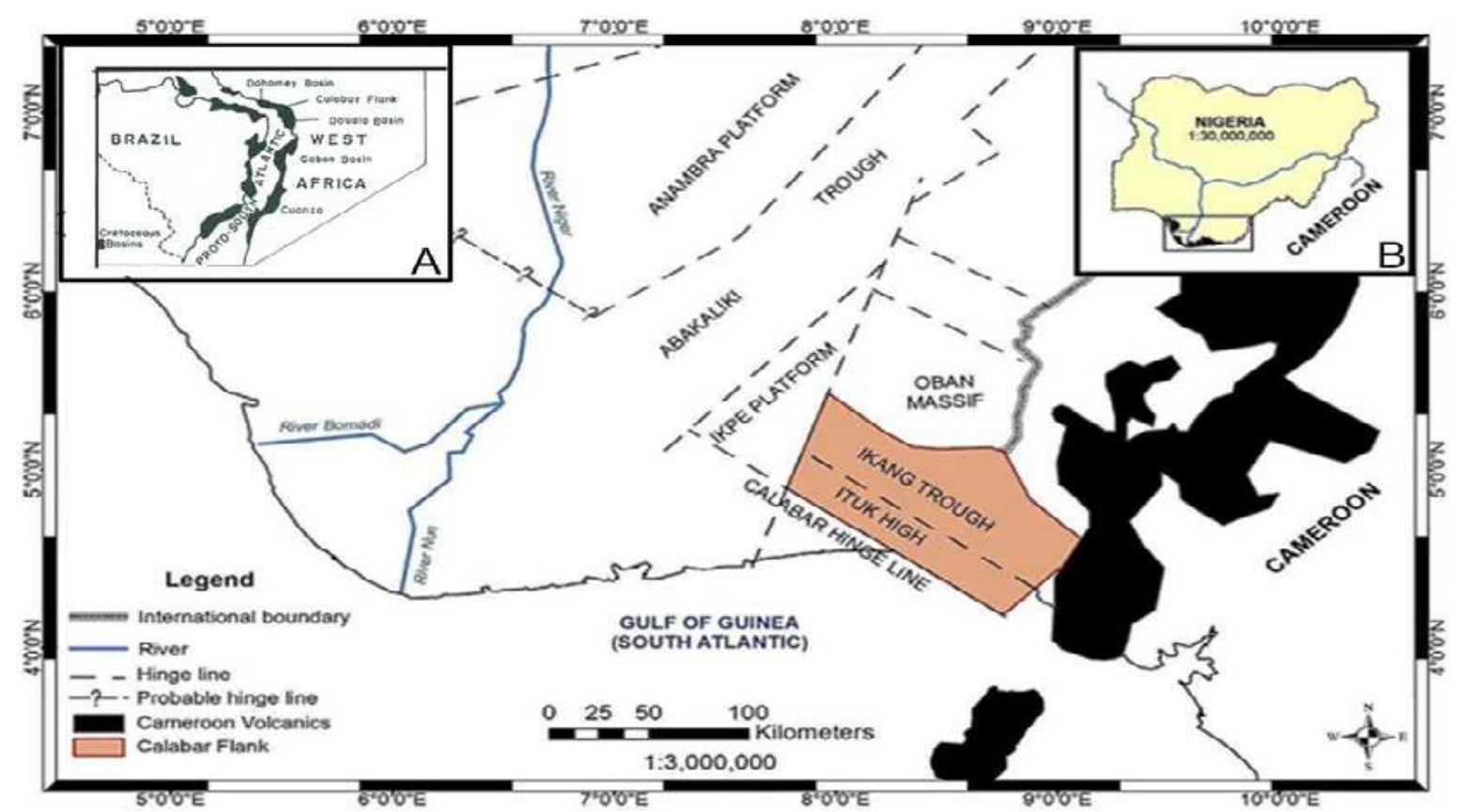

Figure 1: Map of southern Nigeria showing the location of Calabar Flank and its structural elements in relation to adjacent geological features (after Nyong and Ramanathan, 1985)

\section{LOCATION OF STUDY AREA AND GEOLOGY}

The area of study is located within Latitudes $05^{\circ}$ $15^{\prime} 08^{\prime \prime} \mathrm{N}$ and $05^{\circ} 31^{\prime} 08^{\prime \prime} \mathrm{N}$, and Longitudes $008^{\circ} 15^{\prime} 08^{\prime \prime} \mathrm{E}$ and $008^{\circ} 33^{\prime} 00^{\prime \prime} E$ in the Calabar Flank (Fig. 2). The Calabar Flank is part of an X-shaped, fault-controlled depression, formed in the crystalline Basement Complex of the African Craton (Short and Stäuble, 1967) whose origin is associated with the break-up of South America from Africa during the opening of the Gulf of Guinea in the Mesozoic (Fig.1). Its geologic history is associated with that of Southern Nigeria, which has been controlled by three major tectonic phases (Murat, 1972). This resulted in the displacement of the axis of the main basin, giving rise to three successive basins in which Calabar Flank is one. The major tectonic element of the Flank is a hinge zone, which consists structurally of NWSE trending basement horsts (the Oban Massif and the Ituk high), separated by a graben - the Ikang Trough (Petters and Reijers, 1987; Fig. 3).

Different formation names have been proposed by several authors for sediments within the Calabar Flank (Reyment, 1965; Dessauvagie, 1974; Adeleye and Fayose, 1978; Petters, 1982; Petters et al., 1995). The lithostratigraphic succession in the Calabar Flank is presented in Figs 2 and 4. The sedimentary sequence of the Calabar Flank begins with continental clastics, consisting of a fluvio-deltaic sequence of cross -bedded sandstone, claystone, and shale. The unit overlies the Precambrian Oban Massif unconformably and constitute the Awi Formation of Early Cretaceous (probably Aptian age; Adeleye and Fayose, 1978; Nton, 1999). Enhanced subsidence of the faulted blocks resulted in the initiation of a series of marine transgressions. The earliest marine transgression in Middle Albian resulted in the deposition of platform carbonates (Mfamosing Limestone, Petters, 1982).

Overlying the Mfamosing Limestone is the Ekenkpon Shale Formation (Petters et al., 1995) which comprised a thick sequence of black fissile shales with minor but frequent intercalation of marls, calcareous mudstones and shales. This shale sequence was deposited as a result of the second phase marine transgression which was initiated in Late Albian and continued through Turonian times with a break towards the Cenomanian (Nyong and Ramanathan, 1985).

The New Netim Formation, made up of thick marl unit with thin shale intercalations, overlies the Ekenpon Shale Formation. The Santonian and Early Campanian sediments are not encountered in the Calabar Flank as this period is regarded as a period of non deposition / or erosion. The Late Campanian to Maastrichtian sediment of the Nkporo Formation (Reyment, 1965), comprising dark-grey, carbonaceous, 


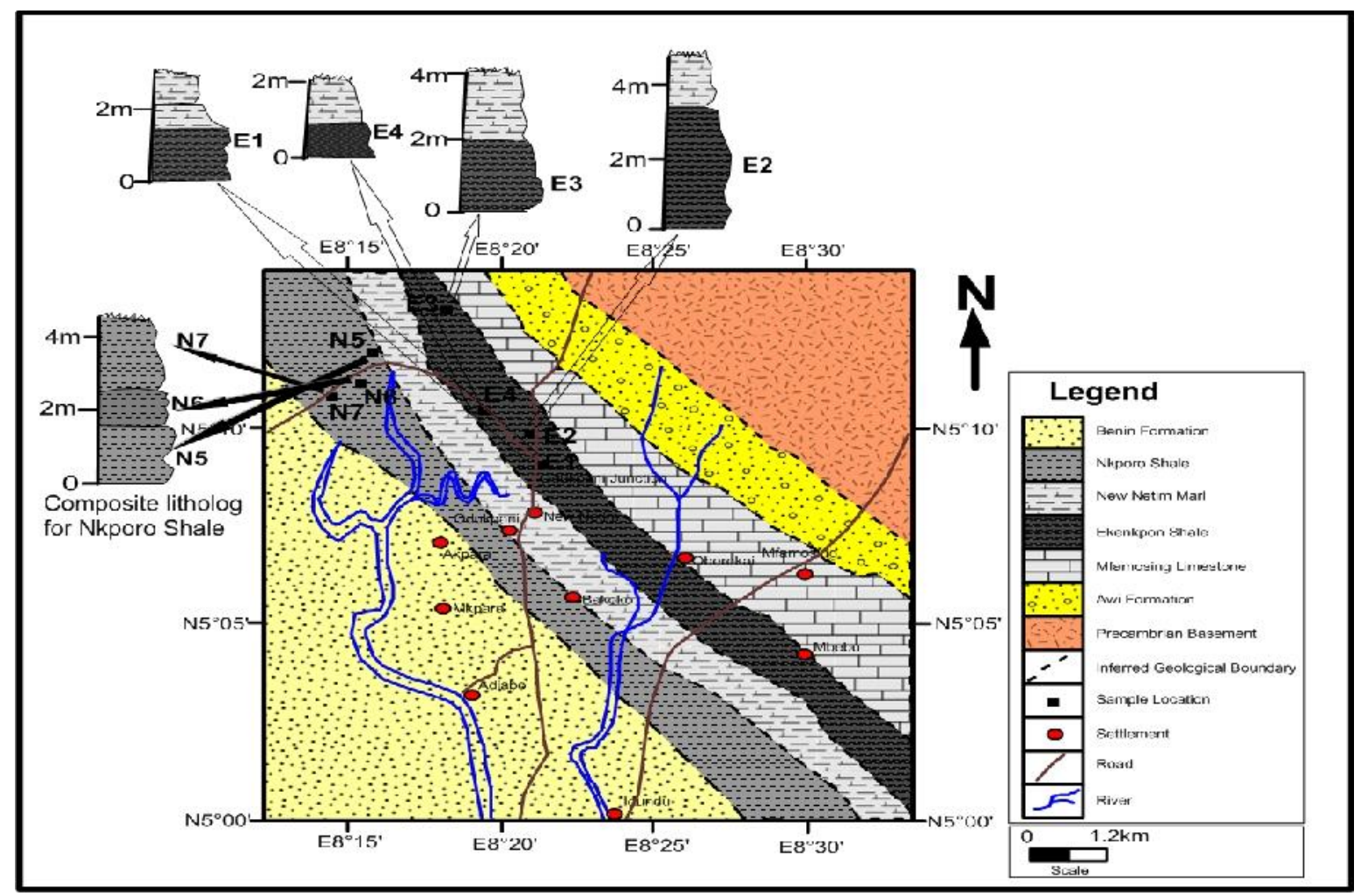

Figure 2: Geologic map of Calabar Flank showing sample locations and stratigraphic sequences (Modified after Ekpo et al., 2013)

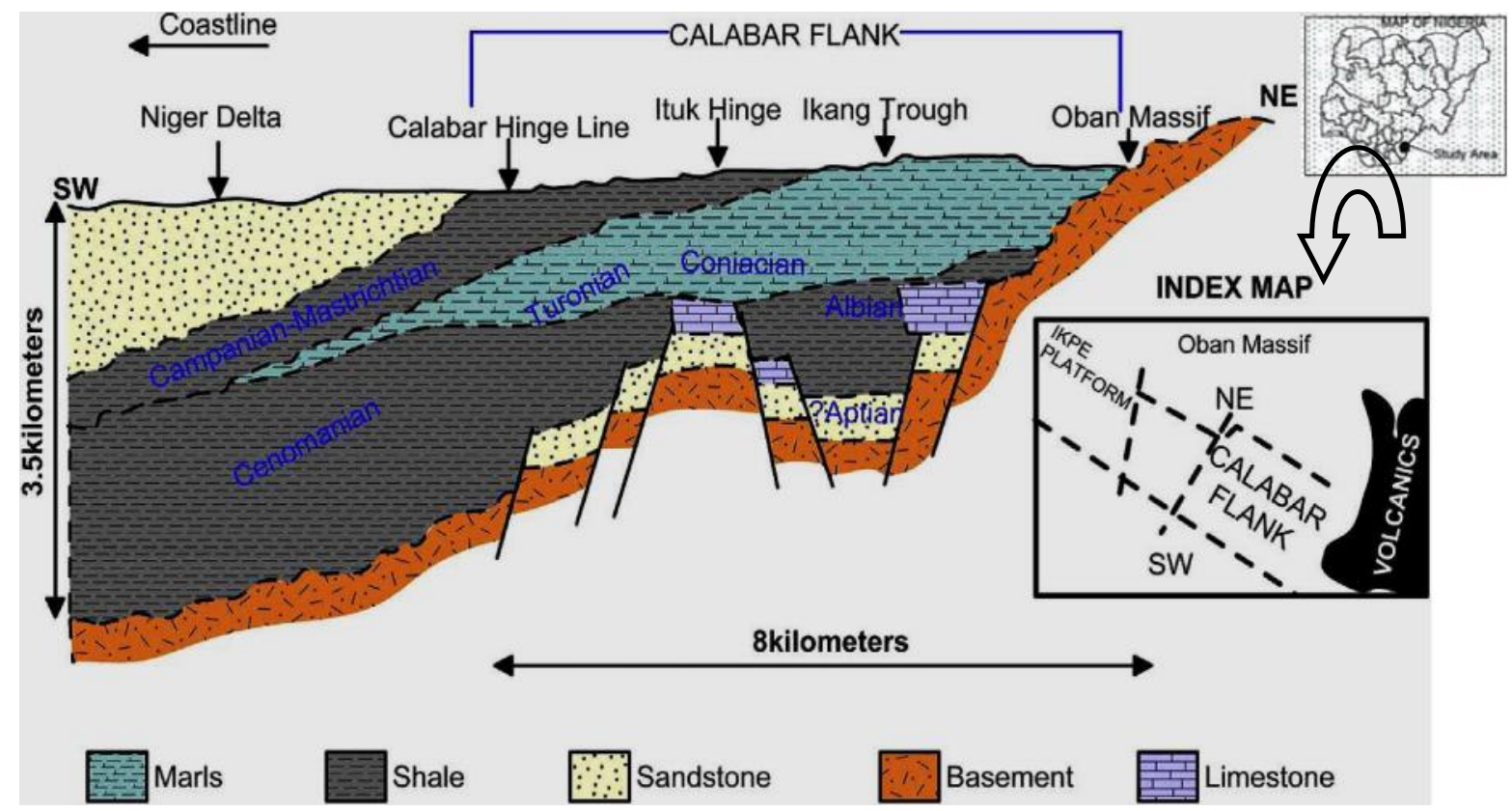

Figure 3: Structural elements and conceptual subsurface distribution of Cretaceous Sediment in the Calabar flank (After Nyong and Ramanathan, 1985) 


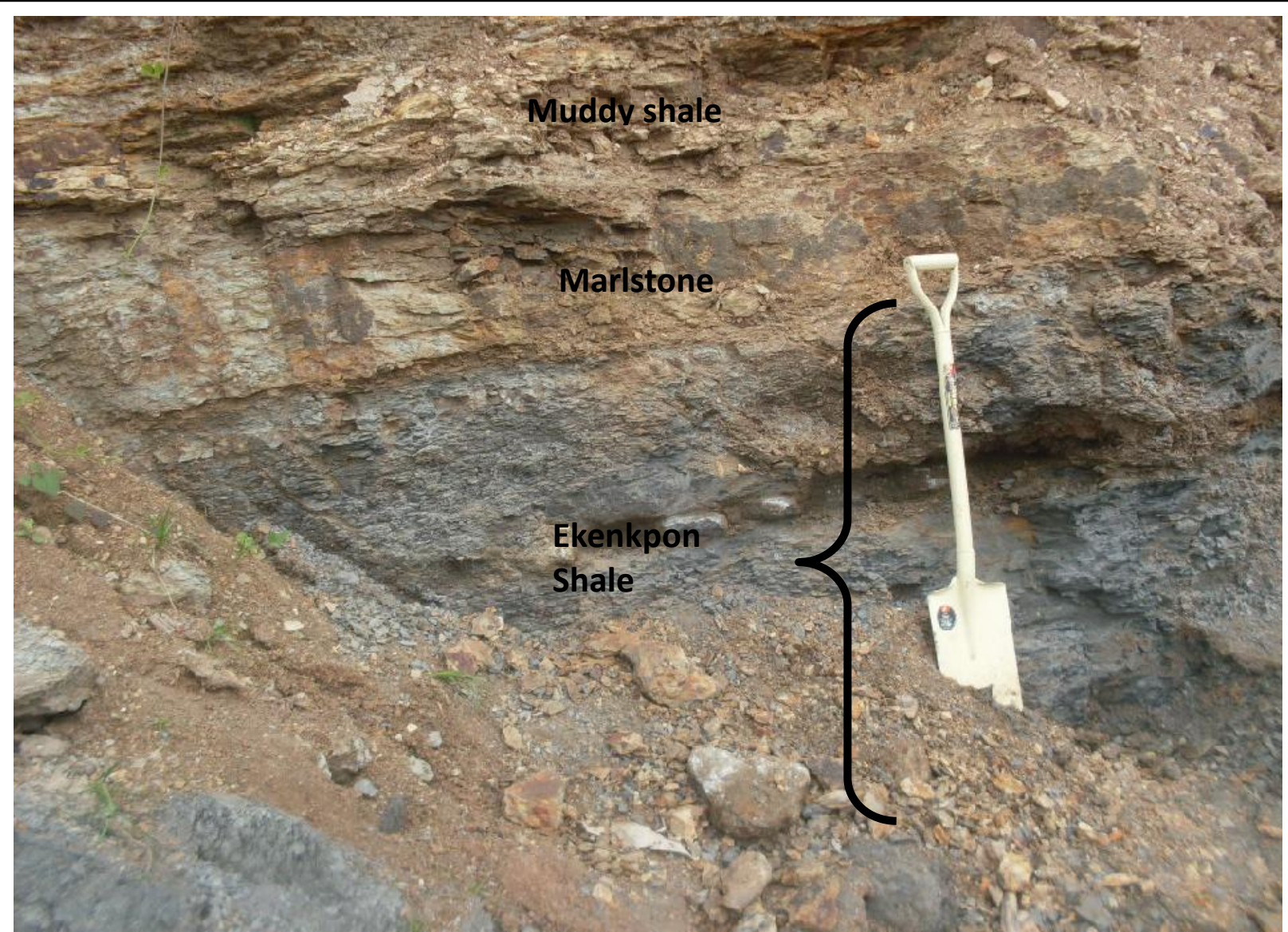

Figure 4: An outcrop location of Ekenkpon Shale at location E1 showing different beds within the outcrop (GPS coordinate: $\left.008^{0} 20^{\prime} 25^{\prime \prime} / 05^{0} 05^{\prime} 51^{\prime \prime}\right)$

\section{METHODOLOGY}

\section{Field Sampling}

Field sampling involving taking vertical profiles of the sedimentary successions and noting variations in lithology, thickness and sedimentary structure was carried out on road cut exposures along the CalabarIkom and Calabar -ltu Roads within the Calabar Flank. Altogether, over thirty (30) samples were collected, made up of sandstone, limestones, marl and shales but seven (7) representative shale samples, made up of four (4) from Ekenkpon and three (3) from Nkporo Formations were used in this study while others are reported elsewhere. Attempts were made at collecting fresh samples at each location. The sampling points were georeferenced and shown in Figs 2 and 4.

\section{Geochemical analyses}

The Ekenkpon and Nkporo Shales were analyzed for major oxides, trace elements and rare earth element (REE) composition. Each sample was digested by weighing $0.2 \mathrm{~g}$ aliquot in a graphite crucible mixed with $1.5 \mathrm{~g} \mathrm{LiBO}_{2} / \mathrm{LiB}_{4} \mathrm{O}_{7}$ flux. The crucibles were placed in an oven and heated at $980^{\circ} \mathrm{C}$ for 30 minutes. The cooled bead was dissolved in $5 \% \mathrm{HNO}_{3}$ (ACS grade nitric acid diluted in demineralised water). Calibration standards and reagent blanks were added to sample sequences. The basic package consisting of thirty-four elements was determined for the shale samples. A second $0.5 \mathrm{~g}$ split sample was digested in Aqua Regia and analysed by Inductively Coupled Plasma-Mass Spectrometer (Perkin-Elmer, Elan 6000) on powdered and pressed pellets to determine $\mathrm{Au}, \mathrm{Ag}, \mathrm{As}, \mathrm{Bi}, \mathrm{Cd}$, $\mathrm{Cu}, \mathrm{Hg}, \mathrm{Mo}, \mathrm{Ni}, \mathrm{Pb}, \mathrm{Sb}$, Se and $\mathrm{Zn}$.

The Inductively Coupled Plasma-Atomic Emission Spectrometry-(ICP-AES) was used for the major elements and some trace elements while Inductively Coupled Plasma-Mass Spectrometry (ICPMS) was used to determine trace and REE concentration. The analyses were conducted at the Acme Analytical Laboratories Ltd., Canada.

\section{RESULTS AND DISCUSSIONS}

\section{Major elements geochemistry}

The results of major element analysis of the samples are shown in Table 1. The major oxide concentrations in Nkporo shale are dominated by $\mathrm{SiO}_{2}$ (45.27\% - 46.45), $\mathrm{Al}_{2} \mathrm{O}_{3}$ (22.27-23.57\%) and $\mathrm{Fe}_{2} \mathrm{O}_{3}$ (8. 39.04wt \%). Other oxides such as $\mathrm{TiO}_{2}, \mathrm{CaO}, \mathrm{Na}_{2} \mathrm{O}$ and $\mathrm{K}_{2} \mathrm{O}$ have respective ranges; $1.00-1.04 ; 0.08-1.82$; $0.07-0.99$ and $1.27-1.54$. The Ekenkpon samples on the other hand; $\mathrm{SiO}_{2}(44.5-54.83 \%)$ and $\mathrm{K}_{2} \mathrm{O}(2.76-$ $5.43 \%)$ but depleted in $\mathrm{Al}_{2} \mathrm{O}_{3}(19.2-20.2 \%)$ and $\mathrm{Fe}_{2} \mathrm{O}_{3}$ (5.64 - 8.24wt \%) compared to Nkporo Shale (Table 1).

The low $\mathrm{K}_{2} \mathrm{O}$ content in Nkporo Shale indicated the low amount of illite or K-feldspar present in the source material, and/or longer transport distance/susceptibility of the source material to high degree of weathering (Akpokodje et al., 1991). Table 2 
summarises the average major element oxide (wt \%) data for the studied samples compare to average shales worldwide (Pettijohn, 1957). On the average, the shale samples are relatively depleted in $\mathrm{SiO}_{2}, \mathrm{MgO}, \mathrm{CaO}$,
$\mathrm{Na}_{2} \mathrm{O}, \mathrm{K}_{2} \mathrm{O}$ and enriched in $\mathrm{Al}_{2} \mathrm{O}_{3}$ and $\mathrm{Fe}_{2} \mathrm{O}_{3}$ compared to average shales from other formations worldwide (Table 2).

Table 1: Major element composition of Ekenkpon Shale and Nkporo Shale sample. Where CIA= Index of Chemical Variation, $\mathrm{CIA}=$ Chemical Index of Alteration, $\mathrm{PIA}=\mathrm{Plagioclase}$ Index of Alteration

\begin{tabular}{|l|l|l|l|l|l|l|l|}
\hline Oxide & N5 & N6 & N7 & E1 & E2 & E3 & E4 \\
\hline $\mathrm{SiO}_{2}$ & 46.45 & 45.27 & 45.59 & 54.83 & 51.30 & 44.50 & 51.60 \\
\hline $\mathrm{Al}_{2} \mathrm{O}_{3}$ & 23.57 & 22.27 & 23.31 & 19.66 & 19.20 & 19.60 & 20.20 \\
\hline $\mathrm{Fe}_{2} \mathrm{O}_{3}$ & 8.30 & 9.04 & 8.40 & 5.64 & 8.24 & 6.69 & 7.30 \\
\hline $\mathrm{MgO}$ & 0.99 & 1.23 & 0.80 & 1.64 & 2.10 & 1.95 & 1.95 \\
\hline $\mathrm{CaO}$ & 0.99 & 1.82 & 0.08 & 1.17 & 1.38 & 0.08 & 1.19 \\
\hline $\mathrm{Na}_{2} \mathrm{O}$ & 0.99 & 0.16 & 0.07 & 1.14 & 0.61 & 0.10 & 0.68 \\
\hline $\mathrm{K}_{2} \mathrm{O}$ & 1.30 & 1.53 & 1.27 & 3.27 & 2.76 & 5.43 & 3.27 \\
\hline $\mathrm{TiO}_{2}$ & 1.00 & 1.04 & 1.04 & 0.96 & 0.98 & 1.07 & 0.77 \\
\hline $\mathrm{P}_{2} \mathrm{O}_{5}$ & 0.10 & 0.10 & 0.12 & 0.16 & 0.10 & 0.17 & 0.12 \\
\hline $\mathrm{MnO}$ & 0.02 & 0.02 & 0.02 & 0.02 & 0.06 & 0.02 & 0.06 \\
\hline $\mathrm{Cr}_{2} \mathrm{O}_{3}$ & 0.02 & 0.02 & 0.02 & 0.01 & 0.01 & 0.01 & 0.01 \\
\hline $\mathbf{A l} \mathbf{O}_{3} / \mathrm{TiO}_{2}$ & 23.57 & 21.41 & 22.41 & 20.48 & 19.59 & 18.32 & 26.23 \\
\hline $\mathrm{K}_{2} \mathrm{O} / \mathbf{A l}_{2} \mathrm{O}_{3}$ & 0.06 & 0.07 & 0.05 & 0.17 & 0.14 & 0.28 & 0.16 \\
\hline $\mathbf{I C V}$ & 0.49 & 0.56 & 0.42 & 0.57 & 0.68 & 0.63 & 0.62 \\
\hline $\mathbf{C I A}$ & 87.78 & 86.38 & 94.26 & 77.89 & 80.17 & 77.75 & 79.72 \\
\hline $\mathbf{P I A}$ & 91.84 & 91.29 & 99.32 & 87.65 & 89.20 & 98.75 & 90.05 \\
\hline
\end{tabular}

Table 2: Average chemical composition of the Nkporo and Ekenkpon shales compared to published average shales

\begin{tabular}{|l|l|l|l|l|l|l|}
\hline Oxide & $\begin{array}{l}\text { Nkporo } \\
\text { Shale }\end{array}$ & $\begin{array}{l}\text { Ekenkpon } \\
\text { shale }\end{array}$ & $\begin{array}{l}\text { Average } \\
\text { Shale } \\
\text { (Pettijohn, } \\
\text { 1957) }\end{array}$ & $\begin{array}{l}\text { Turekan \& \& } \\
\text { Wedephol } \\
\text { (1961) }\end{array}$ & $\begin{array}{l}\text { PASS } \\
\text { (Taylor and } \\
\text { McLennan, } \\
\text { 1985) }\end{array}$ & $\begin{array}{l}\text { NASC } \\
\text { (Gromet et } \\
\text { al., 1984) }\end{array}$ \\
\hline $\mathrm{SiO}_{2}$ & 45.77 & 50.56 & 58.1 & 58.5 & 62.40 & 64.82 \\
\hline $\mathrm{Al}_{2} \mathrm{O}_{3}$ & 22.72 & 19.67 & 15.4 & 15 & 18.78 & 17.05 \\
\hline $\mathrm{Fe}_{2} \mathrm{O}_{3}$ & 8.58 & 6.98 & 6.9 & 4.72 & 7.18 & 5.7 \\
\hline $\mathrm{MgO}$ & 1.01 & 1.91 & 2.4 & 2.5 & 2.19 & 2.83 \\
\hline $\mathrm{CaO}$ & 0.96 & 0.87 & 3.1 & 3.1 & 1.29 & 3.51 \\
\hline $\mathrm{Na}_{2} \mathrm{O}$ & 0.41 & 0.7 & 1.3 & 1.3 & 1.19 & 1.13 \\
\hline $\mathrm{K}_{2} \mathrm{O}$ & 1.37 & 3.68 & 3.2 & 3.1 & 3.68 & 3.97 \\
\hline $\mathrm{TiO}_{2}$ & 1.03 & 0.95 & 0.6 & 0.77 & 0.99 & 0.8 \\
\hline $\mathrm{P}_{2} \mathrm{O}_{5}$ & 0.11 & 0.14 & 0.2 & 0.16 & 0.16 & 0.15 \\
\hline $\mathrm{MnO}$ & 0.02 & 0.04 & Trace & - & - & - \\
\hline $\mathrm{Cr}_{2} \mathrm{O}_{3}$ & 0.017 & 0.011 & Trace & - & - & - \\
\hline
\end{tabular}

Trace, and rare earth elements geochemistry

The trace elements results are shown in Table 3. Ranges of values are; $\mathrm{Ba}(199-284 \mathrm{ppm})$ and $\mathrm{Rb}(62$ $69.8 \mathrm{ppm})$ in Nkporo shale and $\mathrm{Ba}(104-550 \mathrm{ppm})$ and $\mathrm{Rb}(146-230 \mathrm{ppm})$ in Ekenkpon shale. These may be concentrated in K-feldspars and phyllosilicates and are depleted relative to PAAS (average post-Archean Australian average shale; Condie, 1993). Strontium with values ranging from $124-350 \mathrm{ppm}$ and $176-856 \mathrm{ppm}$ respectively for Nkporo and EkenkponShalesis greatly enriched when compared with PAAS, average granite and granodiorite. Similarly, the ranges of Thorium (15.0 - 17.2ppm in Nkporo) and (14.6-23.2ppm in Ekenkpon) are enriched in both formations with respect to PAAS (14.6ppm) and on the average, almost similar to average granite (18ppm) in the Ekenkpon Shale.

It has been reported that $\mathrm{Ti}, \mathrm{Nb}$ and $\mathrm{Hf}$ are preferentially partitioned into melts during fractional crystallization and anatexis (Feng and Kerrich, 1990) resulting in their enrichments in felsic rather than mafic rocks. In this study, Nkporo Shale exhibits nearly values; $\mathrm{Zr}$ (160-191), Hf (4.1-5.3), Nb (20.1-23.9) and $\mathrm{Ti}$ (0.3- 
0.9) in comparison to Ekenkpon shale with $\mathrm{Zr}$ (148.8181.5ppm), Hf (3.9-5.2), Nb (15.8-19.5) and Ti (0.2-1.5). Generally, the samples are enriched in trace elements relative to PAAS and are thus believed to have been sourced from a felsic to intermediate rocks.

The rare earth elements result is shown in Table 4. Samples from both formations are enriched in $\Sigma$ LREE (174.6-284.2ppm) compared to PAAS (166.1ppm) but are depleted in $\Sigma$ HREE (33.41-49.8ppm) relative to 322.18ppm of PAAS. The negative $\mathrm{Eu}$ anomalies $\left(\mathrm{Eu} / \mathrm{Eu}^{*}=0.05-0.08\right.$ and 0.04-0.06) for Ekenkpon and Nkporo Shales respectively may be attributable to the Eu-depleted felsic igneous rocks, i.e. granites and granodiorite, in the source region. The Chondrite normalised REE plot (Figs. 5a and 5b) show that the Ekenkpon and Nkporo Shales are LREE enriched and have a near flat HREE pattern, with negative Eu.

Table 3: Trace element (ppm) composition of Ekenkpon and Nkporo Shale, and Post Archaean Australian Shale (PAAS; Taylor and McLennan, 1985)

\begin{tabular}{|c|c|c|c|c|c|c|c|c|}
\hline Element & N5 & N6 & N7 & E1 & E2 & E3 & E4 & PAAS \\
\hline $\mathrm{Pb}$ & 14.9 & 16.4 & 16.9 & 14.2 & 19.3 & 78.0 & 10.7 & 16.00 \\
\hline $\mathrm{Zn}$ & 201 & 101 & 168 & 49 & 81 & 21 & 56 & 650 \\
\hline $\mathrm{Be}$ & 4 & 1 & $<1$ & 5 & 4 & 8 & 3 & 23 \\
\hline Cs & 5.5 & 4.3 & 5.6 & 9.2 & 11.3 & 20.3 & 12.5 & 5.0 \\
\hline Ga & 28.8 & 26.6 & 26.0 & 29.1 & 24.8 & 29.8 & 26.8 & 1.9 \\
\hline Sn & 4 & 3 & 3 & 4 & 4 & 6 & 3 & 1.6 \\
\hline $\mathrm{Sr}$ & 124.3 & 350.1 & 170.3 & 176.9 & 393.4 & 856.6 & 403.5 & 14.6 \\
\hline Ta & 1.6 & 1.3 & 1.5 & 1.4 & 0.9 & 1.7 & 0.9 & 3.1 \\
\hline w & 1.2 & 1.2 & 1.1 & 1.5 & 1.2 & 2.1 & 1.1 & 150 \\
\hline Mo & 3.8 & 2.5 & 4.6 & 0.5 & 0.3 & 7.3 & 0.4 & 210.0 \\
\hline As & 18.3 & 20.0 & 23.0 & 4.6 & 8.4 & 4.2 & 10.9 & 10.0 \\
\hline $\mathrm{Cd}$ & 6.2 & 1.9 & 50.6 & 3.5 & 0.2 & 0.1 & 0.6 & 55 \\
\hline $\mathrm{Ni}$ & 48.6 & 36.3 & 61.0 & 23.4 & 30.9 & 56.8 & 25.8 & \\
\hline Sc & 19 & 18 & 22 & 14 & 17 & 21 & 16 & \\
\hline $\mathrm{Ba}$ & 203 & 199 & 284 & 550 & 564 & 104 & 316 & \\
\hline Co & 18.1 & 14.4 & 18.9 & 12.0 & 18.3 & 30.9 & 16.9 & \\
\hline $\mathrm{Hf}$ & 5.3 & 4.1 & 4.9 & 5.2 & 3.9 & 4.6 & 4.3 & \\
\hline $\mathrm{Nb}$ & 23.9 & 20.4 & 20.1 & 17.9 & 19.1 & 19.5 & 15.8 & \\
\hline $\mathbf{R b}$ & 69.8 & 64.8 & 62.0 & 146.0 & 146.8 & 230.3 & 157.8 & \\
\hline Th & 15.6 & 17.2 & 15.0 & 23.2 & 18.7 & 19.2 & 14.6 & 14.6 \\
\hline U & 3.7 & 3.5 & 4.2 & 4.3 & 3.3 & 6.2 & 1.9 & 3.1 \\
\hline v & 267 & 191 & 289 & 109 & 122 & 138 & 131 & \\
\hline $\mathrm{Zr}$ & 191.2 & 138.6 & 160.0 & 181.5 & 143.8 & 148.8 & 162.4 & \\
\hline $\mathrm{Cu}$ & 24.7 & 23.9 & 39.4 & 27.0 & 33.8 & 193.3 & 26.9 & \\
\hline $\mathrm{Sb}$ & 0.2 & 0.1 & 0.3 & $<0.1$ & $<0.1$ & $<0.1$ & $<0.1$ & \\
\hline $\mathrm{Bi}$ & 0.3 & 0.3 & 0.3 & 0.4 & 0.4 & 0.7 & 0.4 & \\
\hline $\mathrm{Au}$ & 1.0 & 0.8 & 2.1 & 1.7 & 2.0 & 1.2 & 1.4 & \\
\hline $\mathrm{Hg}$ & 0.03 & 0.03 & 0.03 & $<0.01$ & $<0.01$ & 0.01 & $<0.01$ & \\
\hline TI & 0.5 & 0.3 & 0.9 & 0.2 & 0.2 & 1.5 & 0.2 & \\
\hline $\mathrm{Se}$ & 5.2 & 2.1 & 5.1 & $<0.5$ & $<0.5$ & $<0.5$ & $<0.5$ & \\
\hline
\end{tabular}


Table 4: Rare element composition of Ekenkpon Shale, Nkporo Shale, and Post Archaean Australian Shale (PAAS;

\begin{tabular}{|c|c|c|c|c|c|c|c|c|}
\hline REE & N5 & N6 & N7 & E1 & E2 & E3 & E4 & PAAS \\
\hline La & 51.9 & 53.6 & 53.0 & 43.1 & 59.5 & 63.0 & 44.5 & 38.2 \\
\hline $\mathrm{Ce}$ & 108.5 & 116.2 & 126.0 & 82.3 & 118.7 & 135.6 & 82.2 & 79.6 \\
\hline $\mathrm{Pr}$ & 12.01 & 13.08 & 15.19 & 9.95 & 13.47 & 15.11 & 9.02 & 8.83 \\
\hline $\mathrm{Nd}$ & 46.5 & 49.1 & 60.2 & 36.2 & 52.0 & 59.6 & 33.1 & 33.9 \\
\hline Sm & 8.60 & 8.72 & 11.56 & 6.68 & 8.62 & 10.31 & 5.81 & 5.6 \\
\hline SUm LREE & 227.6 & 240.7 & 266.0 & 178.8 & 252.3 & 284.2 & 174.6 & 166.1 \\
\hline Eu & 1.80 & 1.71 & 2.39 & 1.22 & 1.70 & 1.93 & 1.02 & 1.1 \\
\hline Gd & 6.99 & 6.92 & 8.72 & 4.90 & 7.24 & 7.37 & 4.56 & 4.7 \\
\hline $\mathrm{Tb}$ & 1.08 & 1.07 & 1.21 & 0.77 & 1.01 & 0.95 & 0.71 & 0.8 \\
\hline Dy & 5.62 & 5.33 & 5.17 & 4.00 & 5.61 & 3.91 & 3.86 & 4.7 \\
\hline Ho & 1.10 & 1.09 & 0.91 & 0.71 & 1.00 & 0.71 & 0.77 & 1.0 \\
\hline $\mathrm{Er}$ & 3.13 & 3.02 & 2.50 & 2.10 & 2.17 & 1.83 & 2.24 & 2.9 \\
\hline $\mathrm{Tm}$ & 0.43 & 0.43 & 0.36 & 0.32 & 0.44 & 0.31 & 0.33 & 0.41 \\
\hline $\mathrm{Yb}$ & 2.73 & 2.18 & 2.33 & 2.25 & 2.40 & 2.14 & 2.17 & 2.82 \\
\hline Lu & 0.42 & 0.41 & 0.35 & 0.34 & 0.34 & 0.29 & 0.34 & 0.43 \\
\hline$Y$ & 26.5 & 25.2 & 18.5 & 15.8 & 26.6 & 16.1 & 19.6 & \\
\hline SUT HREE & 49.80 & $4 / .96$ & 42.44 & 32.41 & 49.11 & 35.54 & 35.60 & 322.18 \\
\hline
\end{tabular}

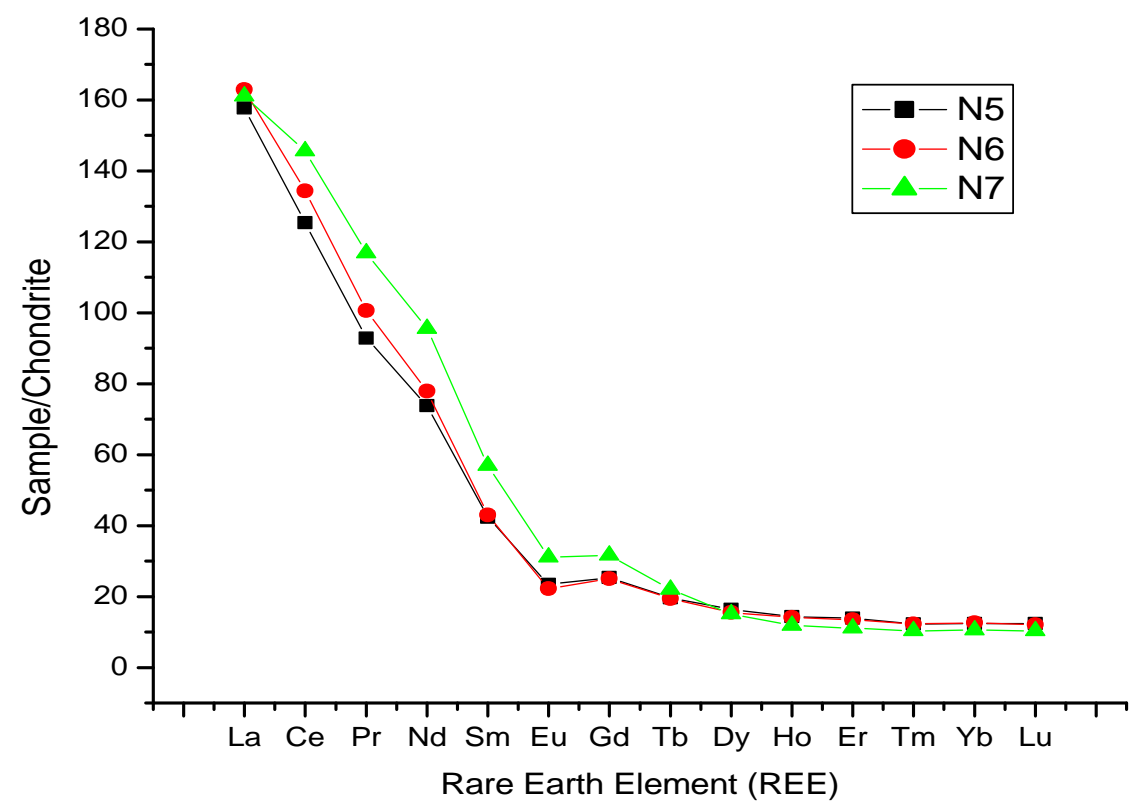

Figure 5a: Plots of Chondrite normalized REE plots for Nkporo shale (After White, 2013) 


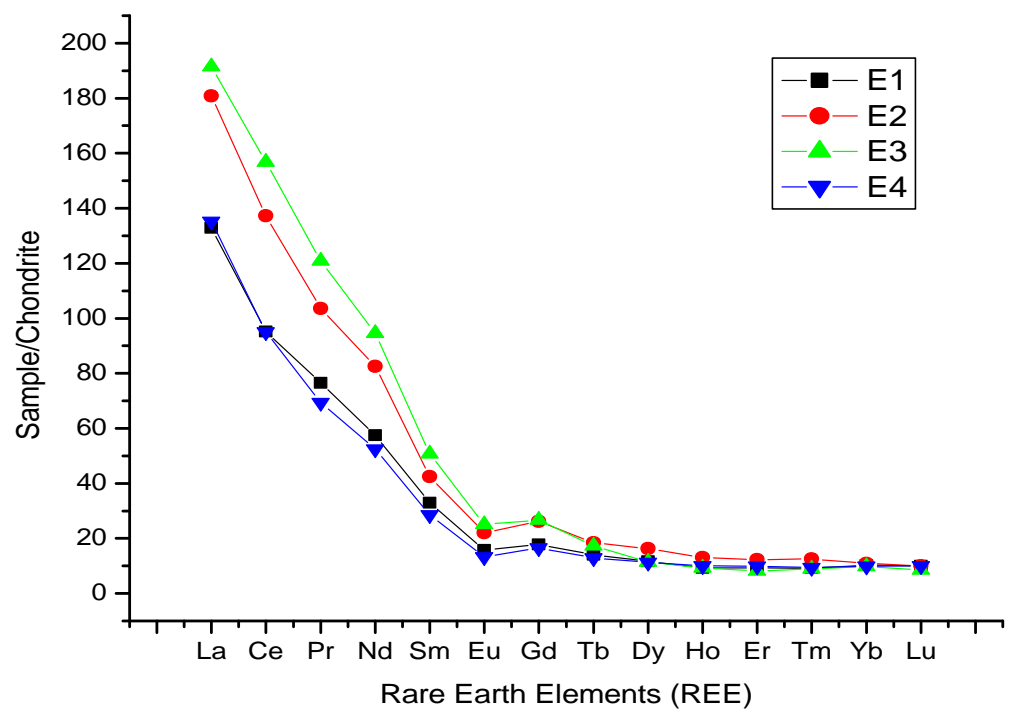

Figure 5b: Plots of Chondrite normalized REE plots for Ekenkpon shale (After White, 2013)

\section{Provenance}

The geochemical signatures of clastic sediments have been used to ascertain the provenance characteristics of such sediments (Taylor and McLennan, 1985; Armstrong-Altrin et al., 2004). It has been reported that the $\mathrm{Al}_{2} \mathrm{O}_{3} / \mathrm{TiO}_{2}$ ratio, increases from 3 to 8 for mafic igneous rocks, 8 to 21 for intermediate rocks, and 21 to 70 for felsic igneous rocks (Hayashi et al., 1997). The Nkporo Shale has $\mathrm{Al}_{2} \mathrm{O}_{3} / \mathrm{TiO}_{2}$ ranges from 21.41 to 23.57 (av. 22.47) while that for Ekenkpon Shale ranges from 18.36 to 26.23 (av. 21.05). These ratios suggest intermediate to felsic source rock.

McLennan et al.(1980), have utilised bivariate plot of $\mathrm{Al}_{2} \mathrm{O}_{3}$ vs. $\mathrm{TiO}_{2}$ to constrain provenance of silliciclastic rocks. In this study, values from such plots, trend towards granodiorite line; especially at the high side extreme of the $\mathrm{Al}_{2} \mathrm{O}_{3}$ axis (Fig. 6). Armstrong-Altrin et al., (2004) and Wrafter and Graham (1989) have reported high Ni content to be associated mainly with ultramafic rock-derived sediments while low $\mathrm{Ni}$ concentration indicates felsic provenance. The $\mathrm{Ni}$ values for this study range from 23.4 to $56.8 \mathrm{ppm}$ in Ekenkpon Shale and 36.3 to $61.0 \mathrm{ppm}$ in Nkporo Shale, suggesting a felsic source rock. Also, comparing the $\mathrm{Th} / \mathrm{Co}, \mathrm{Th} / \mathrm{Sc}$ and $\mathrm{La} / \mathrm{Sc}$ ratios of these samples with those obtained from felsic and basic rocks-derived sediments of upper continental crust (UCC) and PAAS (Culler et al., 1988), it can be deduced that the sediments of Ekenkpon and Nkporo were sourced mainly from felsic rocks (Table 5).

Rare earth patterns can provide information on the pre-metamorphic history of a rock and their patterns have been used to identify the provenance of sedimentary rocks as they remain unchanged even during metamorphism. The europium anomaly in the sedimentary rocks provides important clues regarding the source rock characteristics as well (Taylor and McLennan, 1985). As earlier pointed out, negative Eu anomalies are generally associated with felsic rocks, whereas the mafic rocks exhibit little or no Eu anomalies (Cullers, 1994). The europium anomaly (calculated from the formula: $\mathrm{Eu} / \mathrm{Eu}^{*}$ where $\left.\mathrm{Eu}^{*}=\mathrm{Sm} \times \mathrm{Gd}\right)$ indicate that the analysed samples exhibit negative Eu anomaly ( 0.05 - 0.08; Ekenkpon and 0.04 - 0.06; Nkporo) and further support a felsic source rock (Culler, 1994).

Arising from $\mathrm{Th} / \mathrm{Sc}-\mathrm{Zr} / \mathrm{Sc}$ diagram of McLennan et al, (1993), Condie, (1993), samples from both formations were sourced from felsic volcanic rocks with some contribution from granodioritic rocks (Fig. 7). 


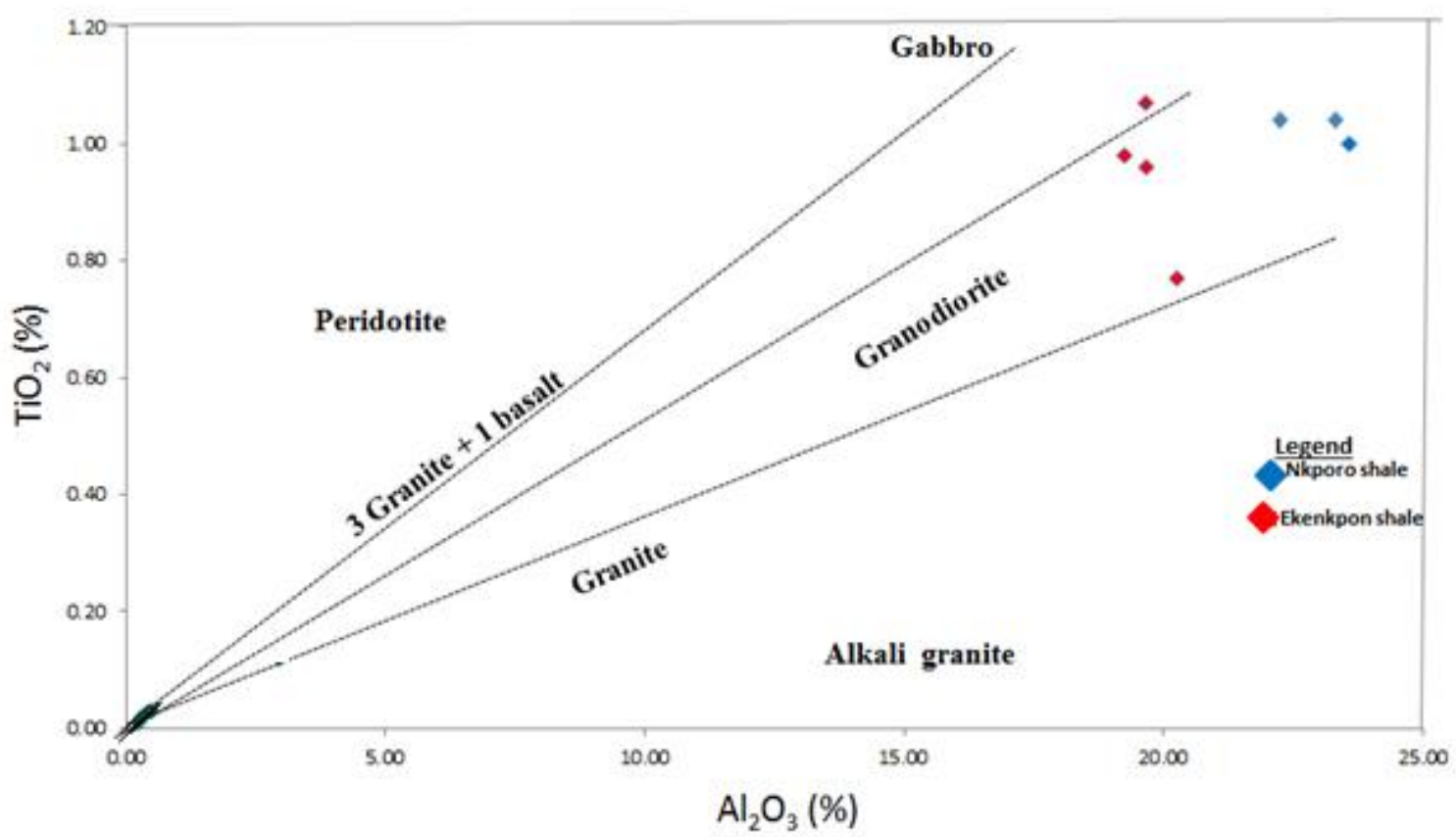

Figure 6: $\mathrm{TiO}_{2}$ wt. \% vs. $\mathrm{Al}_{2} \mathrm{O}_{3}$ wt. \% bivariate diagram Nkporo shale and Ekenkpon shale (McLennan et al., 1980)

Table 5: Range of shale elemental ratios in this study compared to ratios for similar fractions derived from felsic rocks, mafic rocks, upper continental crust and Post-Archean Australia Shale (PAAS)

\begin{tabular}{|l|l|l|l|l|l|l|}
\hline Element ratio & $\begin{array}{l}\text { Ekenkpon } \\
\text { Shale }\end{array}$ & Nkporo shale & $\begin{array}{l}\text { Felsic rocks } \\
\text { derived- } \\
\text { sediment } \\
\text { (Cullers, 1994, } \\
\text { 2000; Cullers et } \\
\text { al., 1988) }\end{array}$ & $\begin{array}{l}\text { Mafic rocks } \\
\text { derived- } \\
\text { sediment } \\
\text { (Culler, 1994, } \\
\text { 2000; Cullers } \\
\text { et al., 1988) }\end{array}$ & $\begin{array}{l}\text { Upper } \\
\text { Continental } \\
\text { Crust (UCC) }\end{array}$ & $\begin{array}{l}\text { Post-Archean } \\
\text { average shale } \\
\text { (PAAS) }\end{array}$ \\
\hline Th/Sc & $0.62-1.93$ & $0.79-1.19$ & $0.84-20.5$ & $0.05-0.22$ & 0.79 & 0.9 \\
\hline Th/Co & $0.91-1.66$ & $0.68-0.96$ & $0.67-19.4$ & $0.04-1.0$ & 0.63 & 0.63 \\
\hline La/Sc & $2.80-3.5$ & $2.4-3.0$ & $2.5-16.3$ & $0.43-0.86$ & 2.21 & 2.4 \\
\hline
\end{tabular}

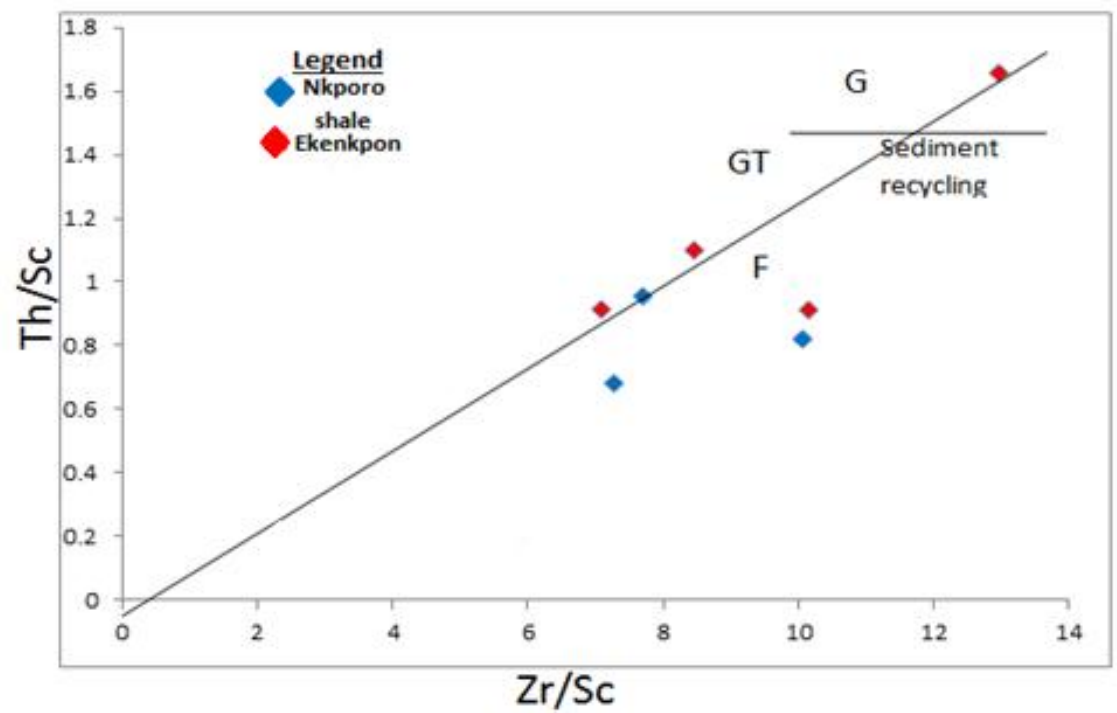

Figure 7: Th/Sc-Zr/Sc diagram for Nkporo and Ekenkpon Formation. G: granite, GT: granodiorite and F: felsic volcanic (After McLennan et al., 1993; Condie, 1993)

Weathering, paleoclimate and transportation history Climate exerts a major control on weathering processes affecting the upper continental crust and evidences of past weathering conditions can be obtained from the products of weathering (Cox et al., 1995). The values of $\mathrm{K}_{2} \mathrm{O} / \mathrm{Al}_{2} \mathrm{O}_{3}$ for the Nkporo Shale 
ranges from 0.05 to 0.07 and that for Ekenkpon Shales are from 0.14 to 0.17 . These indicate preponderance of clay minerals over K-bearing minerals such as Kfeldspars and micas or minimal alkali feldspar in the original shale as proposed by Cox et al., (1995). This clay fraction appears more in the Nkporo shale than the Ekenkpon shale.

The Index of Compositional Variation (ICV; Cox et al., 1995) where ICV = $\left(\mathrm{Fe}_{2} \mathrm{O}_{3}+\mathrm{K}_{2} \mathrm{O}+\mathrm{Na}_{2} \mathrm{O}+\mathrm{CaO}+\mathrm{MgO}+\mathrm{MnO}\right) / \mathrm{Al}_{2} \mathrm{O}_{3}$ can also be used to ascertain the transportational history and the dominant products of weathering. Values of Index of Compositional Variation (ICV) of Nkporo Shale range from 0.42-0.56 while that of Ekenkpon Shale varies from $0.57-0.68$. Values for the study shales are $<1$, and typical of minerals such as kaolinite, illite, plagioclase and muscovite, and also, lower than higher values $(>1)$ expected in rock forming minerals such as biotite, Kfeldspar, amphiboles and pyroxenes (Cox et al., 1995). The values for the shales are still within the clay range. Non-clay minerals have a higher ratio of the major cations such as $\mathrm{Fe}, \mathrm{K}, \mathrm{Na}, \mathrm{Ca}, \mathrm{Mg}$, and $\mathrm{Mn}$ to $\mathrm{Al}$ than clay minerals, making the non-clay minerals have a higher ICV. For example, the ICV decreases in the order, pyroxene and amphibole (10-100), biotite (8), alkali feldspar (0.8-1), plagioclase (0.6), muscovite and illite (0.3), montmorillonite $(0.15-0.3)$ and kaolinite (0.03-0.05) as proposed by Cox et al.(1995). Immature shales with a high percent of non-clay silicate minerals will have ICV > 1 while mature ones have lower ICV values < 1 (Cox et al., 1995). The ICV values for the study samples suggest that the shales are compositionally mature and would have experienced longer transport and/or recycling effects.

Weathering indices of sedimentary rocks can provide useful information on climatic conditions at the source region. Increase in degree of chemical weathering may reflect the decrease in tectonic activity and/or change in climate towards warm and humid conditions (Suttner and Dutta, 1986). The degree of source rock weathering is quantified with different indices. Various known indices of weathering/alteration used in this study and their calculations are; Chemical Index of Alteration $\left(\mathrm{CIA}=\left\{\mathrm{Al}_{2} \mathrm{O}_{3} /\left(\mathrm{Al}_{2} \mathrm{O}_{3}+\mathrm{CaO}+\mathrm{Na}_{2} \mathrm{O}\right.\right.\right.$ $\left.\left.+\mathrm{K}_{2} \mathrm{O}\right)\right\} \times$ 100; Nesbitt and Young, 1982), Plagioclase Index of Alteration (PIA $=\left\{\left(\mathrm{Al}_{2} \mathrm{O}_{3}-\mathrm{K}_{2} \mathrm{O}\right) /\left(\left(\mathrm{Al}_{2} \mathrm{O}_{3}-\mathrm{K}_{2} \mathrm{O}\right)\right.\right.$ $\left.\left.+\mathrm{CaO}+\mathrm{Na}_{2} \mathrm{O}\right)\right\} \times 100$; Fedoet al., 1995) while Chemical Index of Weathering is represented as : $\left(\mathrm{CIW}^{*}=\left\{\mathrm{Al}_{2} \mathrm{O}_{3} /\left(\mathrm{Al}_{2} \mathrm{O}_{3}+\mathrm{Na}_{2} \mathrm{O}\right)\right\} \times 100 ;\right.$ Harnois, 1988). The respective values of $\mathrm{CIA}$ are; $77.75-80.17$ and 86.38 - 94.26 for Ekenkpon and Nkporo Shales; indicative of intensive weathering in the source area. The respective PIA ranges for Ekenkpon and Nkporo Shales are: 87.65 to 98.75 and 91.29 to 99.32 ; suggesting intense destruction of feldspars during the course of source weathering, fluvial transport, sedimentation and diagenesis (Fedo et al., 1995).. During the initial stages of weathering of feldsparbearing source material, $\mathrm{Ca}$ is leached rapidly than $\mathrm{Na}$ and $\mathrm{K}$. With increasing weathering, total alkali content $\left(\mathrm{K}_{2} \mathrm{O}+\mathrm{Na}_{2} \mathrm{O}\right)$ decreases with increase in $\mathrm{K}_{2} \mathrm{O} / \mathrm{Na}_{2} \mathrm{O}$ ratio as evidenced in this study. This is due to destruction of feldspars where plagioclase is preferentially removed than K-feldspars (Nesbitt and Young, 1984).

In sedimentary rocks, Th/U values $>4.0$, may indicate intense weathering in the source areas or recycling. The $\mathrm{Th} / \mathrm{U}$ value of 3.10 to 7.68 (av. 5.46) for Ekenkpon Shale and 3.37 to 4.91 (av. 4.23) for Nkporo Shale portray moderate to high weathering. These support the findings of Adeigbe and Jimoh (2013).

\section{Palaeoenvironment of deposition}

Palaeo-redox conditions during sedimentation of siliciclastic rocks can be evaluated based on their chemical constituents. Typically redox-sensitive elements, such as $\mathrm{V}, \mathrm{Cr}$ and $\mathrm{U}$, provide a means to determining the degree of anoxia during deposition (Madhavaraju and Ramasamy, 1999). Low U concentration is generally associated with sediments deposited in oxygenated marine realm (Madhavaraju and Ramasamy, 1999). The U/Th ratio 1.9 to 6.2 (av. $3.85)$ for the shales indicate deposition in oxic marine setting.

According to Jones and Manning (1994) values of $\mathrm{Ni} / \mathrm{Co}$ ratio $<5$ indicate an oxic environment, whereas values $>5$, suggest suboxic and anoxic environment. The Ni/Co values for Nkporo Shale ranges between 2.75 and 4.49 while that of Ekenkpon Shale is between 2.25 and 2.30; . indicating deposition in oxic environment for the samples. Wilde et al. (1996) linked Ce anomalies in shales of the anoxic facies to eustatic sea level changes. Similar to $\mathrm{Mn}, \mathrm{Ce}^{4+}$ is less soluble under oxic conditions, whereas under anoxic conditions it is mobilized, leading to depletion in $\mathrm{Ce}$ in anoxic sediments relative to those deposited under oxic conditions. Taylor and McLennan (1985) recommended use of the geometric mean;

$$
C e^{*}=(\mathrm{La}+\mathrm{Pr})^{1 / 2} \text {. }
$$

The ratio $\mathrm{Ce} / \mathrm{Ce}^{*}$ is then a measure of the anomaly, with values less than unity, termed negative and greater than unity, positive. Values of this ratio (Table 4) are less than unity: (0.27 - 0.4 for Ekenkpon and $0.31-0.35$ for Nkporo) shales, show negative $\mathrm{Ce}$ anomaly, and support an oxic marine condition. Also, on the AKF; $\left(\mathrm{Al}_{2} \mathrm{O}_{3}\right)-\left(\mathrm{K}_{2} \mathrm{O}+\mathrm{Na}_{2} \mathrm{O}+\mathrm{CaO}\right)-\left(\mathrm{Fe}_{2} \mathrm{O}_{3}+\mathrm{MgO}\right)$ plot (Fig. 8), the sediments were deposited in continental to transitional zone (Fig. 8; Englung and Jorgensen, 1973). 


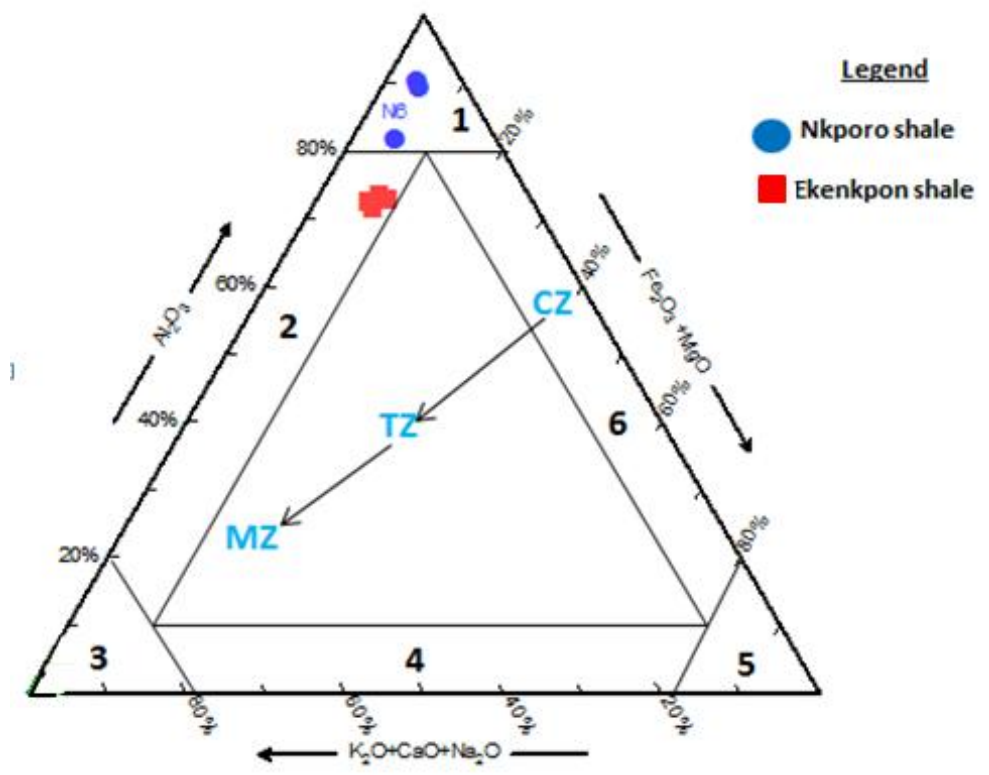

Figure 8: $\mathrm{Al}_{2} \mathrm{O}_{3}-\left(\mathrm{K}_{2} \mathrm{O}+\mathrm{CaO}+\mathrm{MgO}\right)-\left(\mathrm{Fe}_{2} \mathrm{O}_{3}+\mathrm{MgO}\right)[\mathrm{AKF}]$ Ternary plots for Nkporo shale and Ekenkpon shale. 1argillaceous, 2- carbonaceous argillites, 3- carbonaceous, 4-carbonaceous ferrite, 5- ferruginous, 6- ferruginous argillite, $\mathbf{C Z}=$ Continental Zone, $\mathbf{T Z}=$ Transition Zone and $\mathbf{M Z}=$ Marine Zone (after Englung and Jorgensen, 1973)

\section{Tectonic setting}

Several authors have described the usefulness of major, trace and rare earth elements geochemistry of siliciclastic rocks to infer tectonic settings based on discriminant diagrams plots (Bhatia, 1983; Roser and Korsch, 1986). As reported by Oni et al., (2014), plate tectonic processes impart distinctive geochemical signatures to sediments in two parts; tectonic environments have distinctive provenance characteristics and are characterised by distinctive sedimentary processes. Discrimination diagram using log ratios of $\mathrm{K}_{2} \mathrm{O} / \mathrm{Na}_{2} \mathrm{O}$ against $\mathrm{SiO}_{2}$ (Fig. 9) based on Roser and Korsch (1986) points to active continental margin for the study samples. Such a setting, according to Roser and Korsch (1986), is characterised by intermediate quartz or $\mathrm{SiO}_{2}$ content as seen in this study. Using Th-Co-Zr/10 and Th-Sc-Zr/10 and La-ThSc, ternary plots (Figs. $10 \mathrm{a}-\mathrm{c}$ ), the samples from the study area plot in the continental island arc terrain and passive continental margin.

Boboye and Okon (2014) deduced a passive to active continental margin tectonic settings for the sediments of Calabar Flank while Okon et al., (2017) reported mainly passive to active continental margins for the Awi Formation. In a related study in southeastern part of the Niger Delta, Oni et al., (2014) characterised the sediments as belonging to active continental margin tectonic setting. They associated such a setting with actively opening of a failed arm of a triple junction as part of the Cretaceous rift system of West and Central Africa. These may also be associated with the setting in this study. Chin et al., (2013) have opined that the composition of magma in continental arc is a product of mixing between igneous differentiation of mafic magmas and felsic or silica crust melting. 


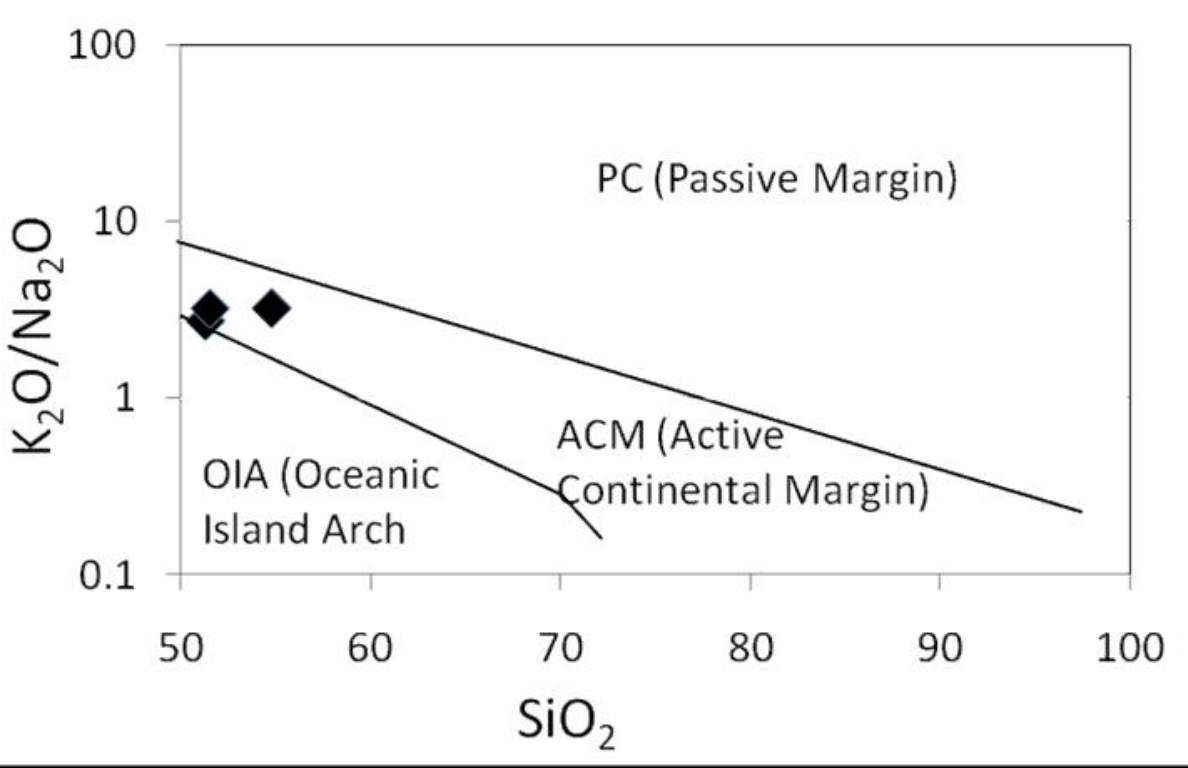

Fig. 9: Tectonic discrimination using the log ratios of $\mathrm{K}_{2} \mathrm{O} / \mathrm{Na}_{2} \mathrm{O}$ vs $\mathrm{SiO}_{2}$ for study samples (after Roser and Korsch, 1986)

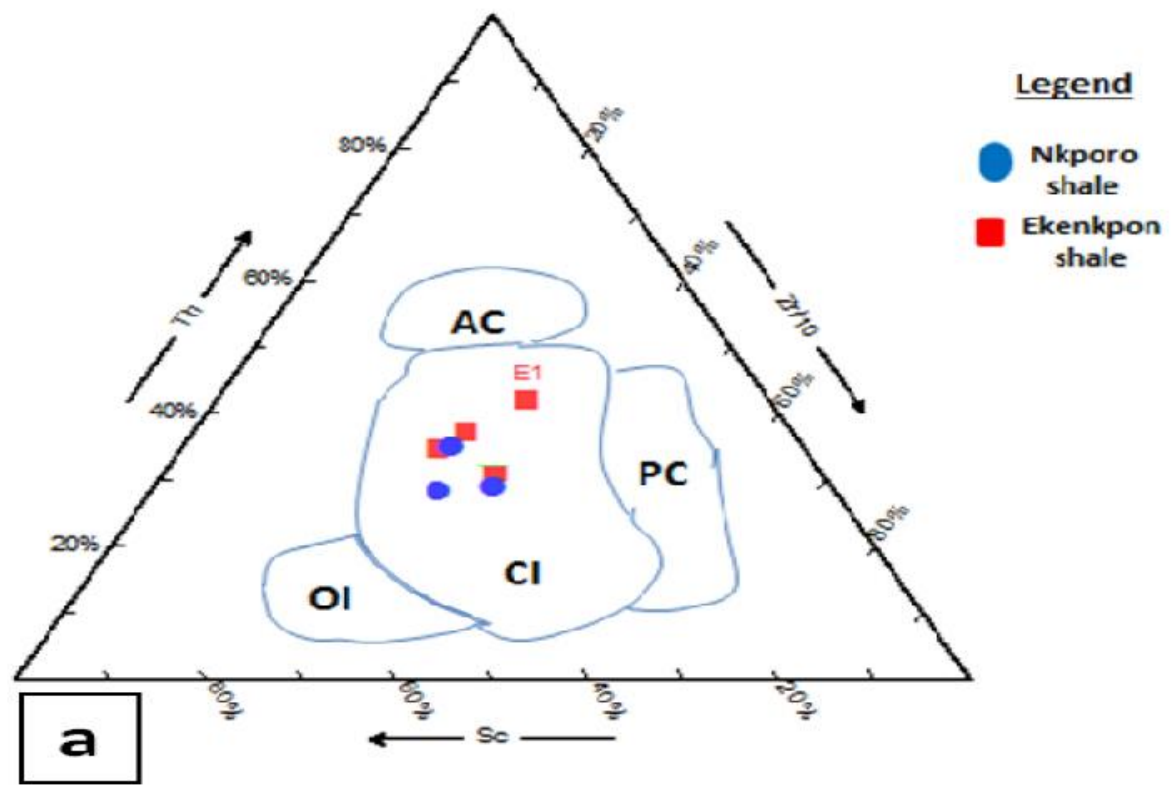



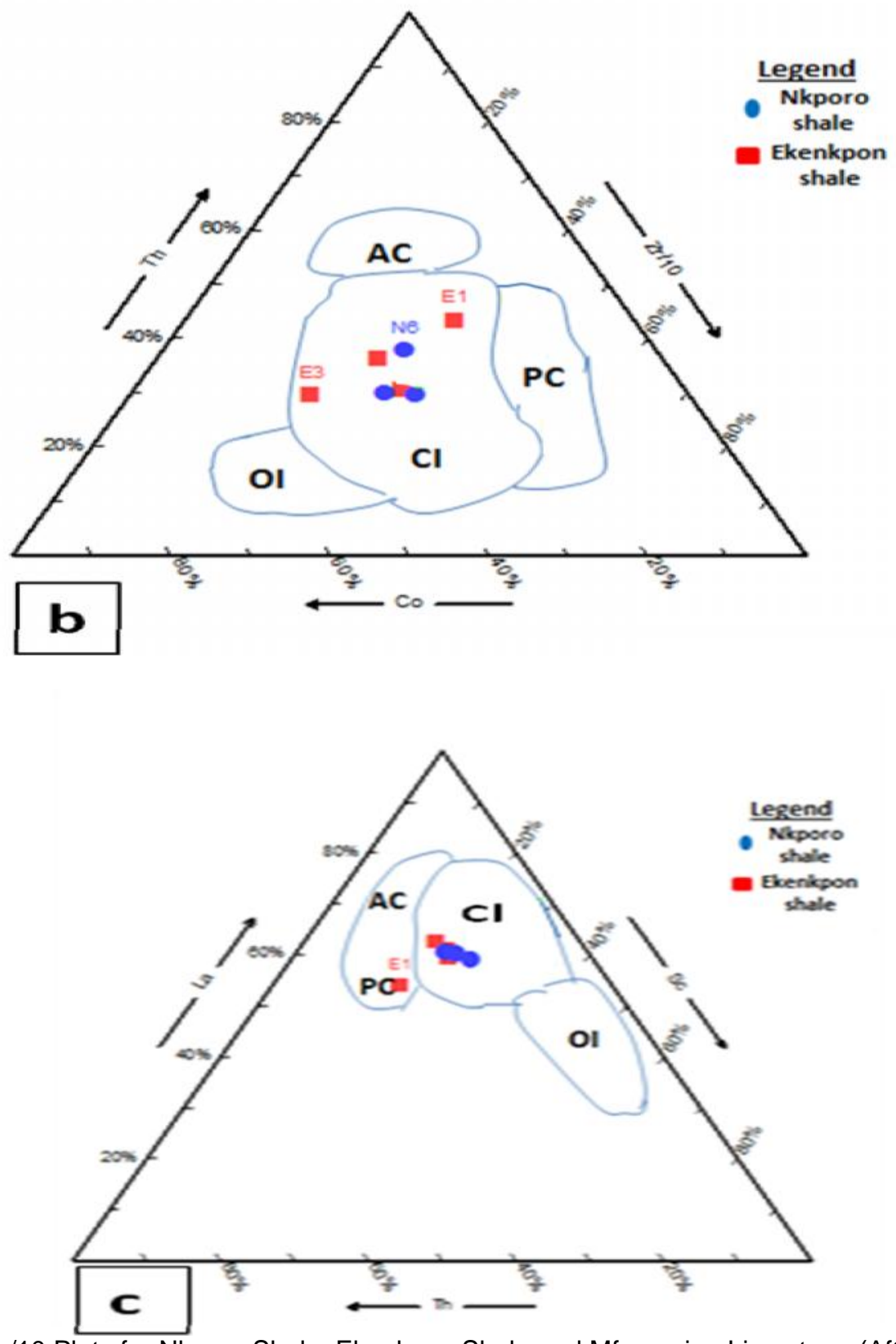

Fig 10a. Th-Sc-Zr/10 Plots for Nkporo Shale, Ekenkpon Shale and Mfamosing Limestone (After Bhatia and Crook, 1986); b. Th-Co-Zr/10 Plots for determination of tectonic settingfor Nkporo shale and Ekenkpon shale (After Bhatia and Crook, 1986); c. La-Th-Sc Plots for determination of tectonic setting for Nkporo shale and Ekenkpon shale (After Bhatia and Crook, 1986). OI= Oceanic Island Arc $\mathbf{C l}=$ Continental Island Arc, $\mathbf{A C}=$ Active Continental Margin, $\mathbf{P C}=$ Passive Margin

\section{CONCLUSIONS}

The geochemistry (bivariant plots of $\mathrm{Al}_{2} \mathrm{O}_{3}$ vs $\mathrm{TiO}_{2}$; ratios of $\mathrm{Th} / \mathrm{Sc}, \mathrm{Th} / \mathrm{Co}$ and $\mathrm{La} / \mathrm{Sc}$ compared to PAAS as well as negative Eu anomalies) of Ekpenkpon and Nkporo Shales in the Calabar Flank shows that the sediments were derived mainly from felsic rocks. The shales would have suffered intense weathering, where feldspars could have been destroyed, resulting in preponderance of clay minerals in the Nkporo Shale than in the Ekenkpon Shale. It is envisaged that the sediments were formed from passive to active tectonic setting and deposited in oxic, continental to transitional marine environment. The tectonic setting is active continental margin and associated passive margin type. Integration of petrology and other chemical proxies from other lithotypes within the area, could further strengthen the deductions of the tectonic evolution of the area.

\section{ACKNOWLEGEMENTS}

The authors are grateful to the anonymous reviewers for the constructive criticisms that have helped to improve the quality of this paper. The assistance of Mr Stephen David, in field sampling, is gratefully 
acknowledged. The first author in particular, wants to use this medium to say a final farewell to Late Prof. Anthony Azubuike Elueze, FNMGS, FGS, of the Department of Geology, University of Ibadan, who has been my mentor, boss and a very dear friend. May his gently soul rests in peace.

\section{REFERENCES}

Adeigbe, O. C and Jimoh, T. A., 2013. Geochemical Fingerprints; Implication for Provenance, Tectonic and Depositional Settings of Lower Benue Trough Sequence, Southeastern Nigeria. Journal of Environment and Earth Science, 3, 10, 2224-3216.

Adeleye, D. R and Fayose, E. A., 1978. Stratigraphy of the type section of Awi Formation, Odukpani Area, South-Eastern Nigeria, Nigeria Journal of Mining Geology.15.1: 35-37.

Armstrong-Altrin, J. S., Lee, Y. I., Verma, S. P and Ramasamy, S., 2004. Geochemistry of sandstones from the upper Miocene Kudankulam Formation, southern India: Implications for provenance, weathering, and tectonic setting. Journal of Sedimentary Research, 74.2, $285-297$.

Akpan, E. B., 1985. Ichnology of the Cenomanian Turonian of the Calabar Flank, SE Nigeria. Geologie en Mijnbouw 64, 365-372.

Akpokodje, E. G., Etu-Efeotor, J. O and Olorunfemi, B. N., 1991. The composition and physical properties of some ceramic and pottery clays of South Eastern Nigeria. Journal Mining and Geology. 27, $9-15$.

Bhatia, M. R., 1983. Plate tectonics and geochemical composition of sandstones. Journal of Geology, 91, 611- 627.

Boboye, O. A and Okon, E. E., 2014. Sedimentological and geochemical characterization of Calabar flank, south eastern Nigeria. Journal of African Earth Science, 99.2, 427-441.

Chin, E. J., Lee, C. A., Tollstrup, D. L., Liewan, X., Wimpenny, J. B and Yin, Q., 2013. On the origin of hot metasediment quarzites in the lower crust of continental arcs. Earth and Planetary Science Letters 361: 120-133.

Condie, K. C., 1993. Chemical composition and evolution of the upper continental crust: contrasting results from surface samples and shales. Chemical Geology, 104:1-37.

Cox, R., Lowe, D. R and Cullers, R. L., 1995. The influence of sediment recycling and basement composition on evolution of mudrock chemistry in the southwestern United States. Geochimica et Cosmochimica Acta, 59, (14): 2919-2940.
Cullers, R. L., 1994. The controls on the major and trace element variation of shales, siltstone and sandstones of Pennsylvanian - Permian age from uplifted continental blocks in Colorado to platform sediment in Kansas, USA. Geochimica et Cosmochimica Acta, 58.22, 4955-4972.

Cullers, R. L., 2000. The geochemistry of shales, siltstones and sandstones of PennsylvanianPermian age, Colorado, U.S.A.: implications for provenance and metamorphic studies. Lithos $51,305-327$

Dessauvagie, T. F. J., 1974. Geological map of Nigeria. Nigerian Mining and Geological Society; Scale 1: $1,000,000$.

Edet, A. E and Okereke, C. S., 2002. Delineation of shallow groundwater aquifers in the Coastal Plains Sands of Calabar area (southeastern Nigeria) using surface resistivity and hydrogeological data. Journal of African Earth Sciences 35 pp 433-443.

Ekpo, B. O., Essien, N. U., Fubara, E. P., Ibok, U. J., Ukpabio, E. J and Wehner, H., 2012. Petroleum geochemistry of Cretaceous outcrops from the Calabar Flank, southeastern Nigeria. Marine and Petroleum Geology, 48, 171-185.

Ekwere, S. J., 1993. Geochemistry of subsurface limestone samples from Etankpine, Calabar Flank, SE Nigeria. Trop. Journ Appl. Science 3, 9-17.

Ekwere, S. J., Esu, E. O., Okereke, C. S and Akpan, E. B., 1994. Evaluation of limestone in Obotme area, southeastern Nigeria for Portland cement manufacture. Journal of $\mathrm{Mi}$ in $\mathrm{g}$ and Geol. 30, (2): 145-150.

Ekwueme, B. N., 1985. The chemical composition and industrial quality of limestones and marls on the Calabar Flank, southeastern Nigeria. Journal of Mining and Geol. 22, (Nos 1\&2): 51-56.

Elueze, A. A., Ntekim, E. E and Ekwere, S. J., 1999. Compositional and industrial assessment of clay bodies in Itu area, southeastern Nigeria. Journal of Mining and Geol. 35, (2): 117-124.

Englund, J.O. and Jorgensen, P., 1973. A chemical classification system for argillaceous sediments and factors affecting their composition. Geol. Stockholm Forh, 95, 87-97.

Essien, N. U., Ukpabio, E. J., Nyong, E. E and Ibe, K. A., 2005. Preliminary organic geochemical appraisal of Cretaceous rock units in the Calabar Flank, southeastern Nigeria. Journal of Mining and Geology, 42, (2): 185-191. 
Esu, E.O and Okereke, C. S., 1990. Preliminary geological appraisal of limestone deposits southwest of Mfamosing village, Akamkpa LGA, Cross River State; upublished Report, 20.

Fedo, C. M., Nesbitt, H. W and Young, G. M., 1995. Unraveling the effects of potassium metasomatism in sedimentary rocks and paleosols, with implications for paleoweathering conditions and provenance. Geology, 23, 921-924.

Feng, R. and Kerrich, R., 1990. Geochemistry of fine grained clastic sediments in the Archean Abitibi greenstone belt, Canada: Implications for Provenance and tectonic setting. Geochim. Cosmochim. Acta, 54:1061 - 1081.

Harnois, L., 1988. The CIW index: a new chemical index of weathering. Sedimentary geology. 55, 319-322.

Hayashi, K., Fujisawa, H., Holland, $\mathrm{H}$ and Ohmoto, H., 1997. Geochemistry of $\sim 1.9 \mathrm{Ga}$ sedimentary rocks from northeastern Labrador, Canada. Geochimica et Cosmochimica Acta, 61, 19, 4115-4137.

Jones, B and Manning, D. C., 1994. Comparison of geochemical indices used for the interpretation of paleo redox conditions in Ancient mudstones: Chemical Geology, 111, 1-4, 111-129.

Madhavaraju, J and Ramasamy, S., 1999. Rare earth elements in limestones of Kallankurichchi Formation of Ariyalur Group, Tiruchirapalli, Cretaceous, Tamil Nadu. Journal of the Geological Society of India, 54, 291-301.

McLennan, S. M., Hemming, S., McDanniel, D. K and Hanson, G. N., 1993. Geochemical approaches to sedimentation, provenance, and tectonics. In: Johnsson, M.J., Basu, A. (eds.). Processes Controlling the Composition of Clastic Sediments. Geological Society of America, Special Paper, 285, 21-40.

Murat, R. C., 1972. Stratigraphy and paleogeography of Cretaceous and Lower Tertiary in southern Nigeria. In African Geology, Proc. Conf: on African Geology. University Press Ibadan, 251266.

Nesbitt, H. W and Young, G. M., 1982. Early Proterozoic climates and plate motions inferred from major element chemistry of lutites. Nature, 199, 715-717.

Nesbitt, H. W and Young, G.M., 1984. Prediction of some weathering trends of plutonic and volcanic rocks based on thermodynamics and kinetic consideration. Geochimica et Cosmochimica Acta, 48, 1223-1234.
Nton, M. E., 1999. Sedimentology and depositional environment of Awi Formation, Calabar Flank, SE Nigeria. Journal of Mining and Geology, 35, $23-36$.

Nyong, E. E and Ramanathan, R. M., 1985. A record of oxygen-deficient paleoenvironments in the Cretaceous of the Calabar Flank, SE Nigeria. Journal of African Earth Sciences 3, (4): 455460.

Odumodu, C. F., 2012. Temperatures and Geothermal Gradient Fields in the Calabar Flank and Parts of the Niger Delta, Nigeria. Petroleum Technology Development Journal, 2, (2): 1 - 15.

Okon, E. E., Essien, N. U and Adeyemi, G. O., 2017. Geochemistry of sandstones of Awi Formation, southeastern Nigeria: Implications for weathering, provenance and tectonic settings. International Journal of Science and Technology, 6, (4): 742-755.

Oni, S. O., Olatunji, A. S and Ehinola, O. A., 2014. Determination of provenance and tectonic settings of Niger Delta clastic facies using Well $-Y$, onshore Delta State, Nigeria. Hindawi Publishing Corporation. Journal of Geochemistry, ID 960139, 13 pages.

Petters, S. W., 1980. Biostratigraphy of Upper Cretaceous Foraminifera of the Benue Trough, Nigeria. Journal of Foraminiferal Research, 10, 191-204.

Petters, S. W., 1982. Central West African CretaceousTertiary benthic foraminifera and stratigraphy. Palaeontographic Abt Av. 179, Ltg. 1 - 3, 1104.

Petters, S. W and Ekweozor, C. M., 1982. Origin of MidCretaceous black shales in the Benue Trough, Nigeria. Paleogeography, Paleoclimate,. Paleoecology, 40, 311-314.

Petters, S. W and Reijers, T. J. A., 1987. Depositional environment and diagenesis of Albian carbonates in Calabar Flank, S. E. Nigeria: Journal of Petroleum Geology. (10), 283-294.

Petters, S. W., Nyong, E. E., Akpan, E. B and Essien, N. U., 1995. Lithostratigraphy revision for the Calabar flank, SE Nigeria. In proc. of the $31^{\text {st }}$ ann. conf. of the NMGS, Calabar.

Pettijohn, F. J., 1957. Sedimentary Rocks, 2nd Edn. Harper \& Row, New York.

Reyment, R. A., 1965. Aspect of the Geology of Nigeria. Ibadan Univ. press, Ibadan, Nigeria, 445.

Roser, B. P and Korsch, R. J., 1986. Determination of tectonic setting of sandstone -mudstone suites using $\mathrm{SiO}_{2}$ content and $\mathrm{K}_{2} \mathrm{O} / \mathrm{Na}_{2} \mathrm{O}$ ratio. Journal of Geology Vol. 93, 635-650. 
Roser, B. P and Korsch, R. J., 1988. Provenance signatures of sandstone-mudstone suites determined using discriminant function analysis of major-element data. Chemical Geology, 67, 119-139.

Short, K.C and Stäuble, A. J., 1967. Outline of geology of Niger delta. American Association of Petroleum Geologist Bulletin, 51, 761-779.

Suttner, L. J and Dutta, P. K., 1986. Alluvial sandstone composition and paleoclimate. Framework mineralogy. Journal of Sedimentary Petrology, 56, 3, 329-345.
Taylor, S. R and McLennan, S., 1985. The Continental Crust: Its composition and Evolution. Oxford, Blackwell, 312.

Wilde, P., Quinby-Hunt, M. S and Erdtmann, B. D., 1996. The whole-rock cerium anomaly: a potential indicator of eustatic sea-level changes in shales of the anoxic facies. Sediment. Geol., 101, 2, 43 -53 .

Wrafter, J. P and Graham, J. R., 1989. Ophiolitic detritus in the Ordovician sediments of South Mayo Ireland. Journal of the Geological Society, London 146:213-215. 